\title{
Pemanfaatan JBclass untuk Meningkatkan Motivasi Belajar Geografis Siswa Selama Masa Pandemi Covid-19 di Resmi Bisma Paket C Kalimanah
}

\section{Utilization of JBclass to Increase Students 'Geographic Learning Motivation During the Covid-19 Pandemic Period in the Official Bisma Paket C Kalimanah}

\author{
Desi Wulandari ${ }^{1}$, Sriyanto ${ }^{2}$ \\ ${ }^{1,2}$ Magister PIPS, Universitas Muhammadiyah Purwokerto
}

\begin{abstract}
ARTICLE INFO
Article history:

DOI:

10.30595/pssh.v1i.85

Submitted:

April 12, 2021

Accepted:

June 10, 2021

Published:

ABSTRACT

Motivation to learn geography for class X Official Bisma Paket C Kalimanah students by utilizing JBClass during the COVID19 pandemic. This paper is a best practice that is carried out in the odd semester of the 2020/2021 school year. The target of this best practice is class X official Bisma Paket C Kalimanah students. The steps for solving problems in this best practice are the use of JBClass as online learning during the COVID-19 pandemic. The instruments of this best practice are the material features, assignments, evaluations and recap of the scores that are on the JBClass. The best practice results show that the use of JBClass in online learning during the COVID-19 pandemic can increase the motivation to learn Geogarafi for class X Official Bisma Paket C Kalimanah for the 2020/2021 school year. Increased motivation to learn geography can be seen from the increase in the average score of assignments and evaluations per class and the timeliness of the work in taking lessons with JBClass during the COVID-19 pandemic.
\end{abstract}

June 14, 2021

\section{Keywords:}

JBClass, Covid-19, Learning Motivation, Pandemic Period, Package C Kalimanah
This work is licensed under a Creative Commons Attribution 4.0 International License.

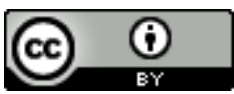

\section{Corresponding Author:}

Desi Wulandari

Magister PIPS, Universitas Muhammadiyah Purwokerto

Jalan KH. Ahmad Dahlan, PO BOX 202 Purwokerto, 53182, Kembaran, Banyumas, Jawa Tengah, Indonesia.

Email: desigeografi49@gmail.com

\section{PENDAHULUAN}

Dikutip dari Kamus Besar Bahasa Indonesia (KBBI), pandemi adalah wabah yang berjangkit serempak di mana-mana atau meliputi geografi yang luas. Pandemi COVID19 sudah berdampak ke berbagai sektor kehidupan seperti ekonomi, sosial, termasuk juga pendidikan. Jika kondisi seperti ini terus meningkat, maka sudah bisa dipastikan dampaknya terhadap sektor pendidikan juga akan semakin meningkat. Dampak yang paling dirasakan adalah peserta didik di instansi penyelenggara pelayanan pendidikan, seperti sekolah disemua tingkatan, lembaga pendidikan non formal hingga perguruan tinggi.

Pandemi Corona Virus Disease 2019 (Covid-19) di Indonesia mengharuskan sekolah menghentikan proses pembelajaran tatap muka. Sebagai gantinya, pembelajaran dilakukan dengan pembelajaran jarak jauh atau remote learning. Pembelajaran secara daring saat ini sesuai dengan Surat Edaran Menteri Pendidikan dan Kebudayaan Nomor 36962/MPK.A/HK/2020. Dampak pandemi COVID-19 di bidang pendidikan sangatlah besar setelah dikeluarkannya Surat Edaran Mendikbud No 4 Tahun 2020. Dalam surat tersebut dijelaskan adanya arahan pendidikan terkait dengan beberapa hal yaitu: dibatalkannya Ujian Nasional, belajar dari rumah, pelaksanaan Ujian 
Sekolah Secara Daring, pelaksanaan ujian kenaikan kelas tanpa mengumpulkan siswa, pelaksanaan PPDB secara daring, dan pemakaian dana BOP untuk membiayai pencegahan COVID 19.

Untuk ketentuan belajar dari rumah ada hal-hal yang perlu diperhatikan oleh guru yaitu : Pembelajaran Jarak Jauh (PJJ) difokuskan pada pendidikan kecakapan hidup, Hasil kerja peserta didik diberi umpan balik yang bersifat kualitatif dan berguna dari guru, Aktivitas dan tugas pembelajaran harus bervariasi dengan memperhatikan fasilitas yang ada pada peserta didik, dan Pembelajaran daring atau jarak jauh, memberikan pengalaman belajar yang bermakna tanpa terbeban tuntutan capaian kurikulum untuk kenaikan kelas dan kelulusan.

Pembelajaran jarak jauh merupakan hal baru bagi guru dan peserta didik Resmi Bisma Paket C Kalimanah. Pada awal pembelajaran online masa pandemi COVID-19, penulis berusaha menggunakan media WhatsApp (WA) dan email untuk memberikan materi dan penugasan kepada peserta didik. Pemilihan media ini karena WhatsApp (WA) dan email merupakan media yang familiar dan mudah baik bagi guru maupun peserta didik. Hasil dari pembelajaran tersebut, peserta didik diminta untuk mengumpulkan tugas berupa file word/gambar ke email guru yang bersangkutan. Namun, ternyata pengumpulan tugas dengan menggunakan WA atau dikirim ke email tersebut mengalami banyak kendala. Ketika tugas dikirim lewat WA guru, tidak jarang banyak peserta didik yang terlambat mengumpulkan tugasnya ke guru karena alasan lupa, ketiduran, tidak punya kuota, membantu orang tua di rumah atau yang lainnya. Untuk mengatasi hal tersebut, guru harus menyediakan waktunya untuk mengecek kelengkapan tugas dari semua peserta didik yang diampunya.

Terkadang juga kendala teknis, peserta didik kesulitan mengirim tugasnya dalam bentuk file ke email gurunya, sehingga tugas belum terkirim ke email guru yang bersangkutan. Beberapa kendala tersebut dan banyaknya hal yang harus ditangani guru dalam pembelajaran jarak jauh menyebabkan peserta didik tidak bisa segera melihat hasil tugasnya secara cepat sehingga menyebabkan peserta didik kurang termotivasi untuk mengikuti pembelajaran online berikutnya. Hal itu bisa dilihat dari adanya beberapa peserta didik yang tidak mengikuti pembelajaran online dan tidak mengumpulkan tugasnya tepat waktu, dampaknya guru yang harus mengingatkan hal tersebut di group WA kelasnya.

Dari beberapa masalah diatas menunjukkan bahwa motivasi peserta didik dalam mengikuti pembelajaran online di awal masa pandemi Covid-19 masih kurang. Dari beberapa permasalahan tersebut akhirnya penulis memutuskan untuk memanfaatkan LMS (learning management sistem) untuk meningkatkan motivasi belajar peserta didik dan memudahkan guru dalam melangsungkan pembelajaran secara online dengan menggunakan JBClass. Pemanfaatan JBClass berpijak pada permasalahan rendahnya motivasi siswa dalam pembelajaranan bahasa Inggris selama masa pandemi COVID-19. Tujuan pemanfaatan JBClass yaitu untuk meningkatkan motivasi geografi pesrta didik kelas X Resmi Bisma Paket C Kalimanah selama masa pandemi COVID-19.

\section{METODE PENELITIAN}

Pada awal pembelajaran online masa pandemi COVID-19, penulis menggunakan media WhatsApp (WA) dan email untuk memberikan materi dan penugasan kepada peserta didik. Pemilihan ini karena WhatsApp (WA) dan email merupakan media yang familiar dan mudah baik bagi guru maupun peserta didik. Hasil dari pembelajaran tersebut, peserta didik diminta untuk mengumpulkan tugas berupa file word/ gambar ke email guru yang bersangkutan.

Permasalahan mulai terjadi ketika beberapa file tugas peserta didik tidak dinamai dengan lengkap sehingga guru harus mengklarifikasi tentang pemilik file tersebut. Karena di email tidak ada pembagian kelas otomatis, guru harus membuat kelas-kelas sendiri dan memindahkan tugas-tugas tersebut supaya guru mudah melakukan pengecekan tugas dari peserta didik yang diampunya. Terkadang juga kendala teknis, peserta didik kesulitan mengirim tugasnya dalam bentuk file ke email gurunya, sehingga tugas belum terkirim ke email guru yang bersangkutan.

Beberapa kendala tersebut dan banyaknya hal yang harus ditangani guru dalam pembelajaran jarak jauh menyebabkan peserta didik tidak bisa segera melihat hasil tugasnya secara cepat sehingga menyebabkan peserta didik kurang termotivasi untuk mengikuti pembelajaran online berikutnya. Hal itu bisa dilihat dari adanya beberapa peserta didik yang tidak mengikuti pembelajaran online dan tidak mengumpulkan tugasnya tepat waktu, dampaknya guru yang harus mengingatkan hal tersebut di group WA kelasnya. Permasalahan kurangnya motivasi belajar bahasa Inggris peserta didik pada masa pandemi COVID-19 diatasi dengan memanfaatkan JBClass untuk melakukan pembelajaran jarak jauh.

Karena JBClass memfasilitasi android untuk penggunaan aplikasinya maka peserta didik dapat mempelajari materi, mengerjakan latihan, tugas, dan evaluasi dengan menggunakan HP androidnya untuk belajar dari rumah. Pada pembelajaran minggu berikutnya guru mengupload materi, latihan, tugas, kemudian peserta didik mempelajari dan mengerjakan latihan dan tugas sesuai jadwal yang diberlakukan di sekolah (jadwal kbm daring). Apabila ada hal yang belum dipahami oleh peserta didik, mereka bisa menanyakannya lewat WA kepada guru tersebut. Diasumsikan pada pembelajaran minggu selanjutnya peserta didik sudah paham tentang materi tersebut sehingga guru mengupload evaluasi kemudian peserta didik mengerjakannya. Jika hasil evaluasi belum tuntas, peserta didik bisa melakukan remidial test setelah mendapatkan ijin dari guru. 
Pada awal pembelajaran online dengan menggunakan JBClass, masih ada beberapa peserta didik yang belum paham tentang penggunaan fitur yang ada di JBClass, sehingga ada yang masih salah dalam mengerjakan tugasnya. Seharusnya tugas essay dikerjakan langsung di fitur tugas tapi masih dikerjakan di buku tulis dan difoto kemudian dikirim lewat WA ke gurunya. Pada waktu pengerjaan tugas juga masih ada peserta didik yang belum paham, sehingga masih banyak peserta didik yang melewati batas waktu pengerjaannya. Hal ini dapat dilihat dari tabel perbandingan pengumpulan tugas 1 (berbentuk essay) dan tugas 2 (tugas pilihan ganda/PG) pada materi Atmosfer dari Kelas X yang diampu sebagai berikut :

Tabel 1. Perbandingan Jumlah peserta didik yang terlambat dalam pengumpulan tugasnya

\begin{tabular}{|c|c|c|c|}
\hline No & Kelas & \multicolumn{2}{|c|}{ Perbandingan Jumlah peserta didik yang terlambat dalam } \\
\hline & & Tugas 1 Essay & Tugas 2 Pilihan Ganda \\
\hline 1 & X IPS 1 & 25 & 2 \\
\hline 2 & X IPS 2 & 20 & 4 \\
\hline
\end{tabular}

Pada tabel diatas terlihat bahwa pada pengumpulan tugas 2 (tugas pilihan ganda) pada materi Atmosfer sudah mengalami perubahan yang cukup signifikan. Jumlah peserta didik yang terlambat dalam pengumpulan tugas sudah semakin sedikit karena peserta didik sudah semakin paham tentang waktu pengumpulan tugasnya.

Untuk fitur tugas, peserta masih dapat mengerjakan soal walaupun waktu sudah habis, tapi akan ada tulisan "tidak tepat waktu" di hasil pengerjaan mereka. Sedangkan untuk fitur evaluasi, setelah waktu habis, soal evaluasi tidak akan muncul di layar sehingga peserta didik harus meminta ijin guru untuk mereset waktu pengerjaan lagi.

\section{HASIL DAN PEMBAHASAN}

Pembelajaran online dengan memanfaatkan JBClass sebagai LMS (learning management system) pada masa pandemi COVID-19 menunjukkan hasil yang bagus. Dengan memanfaatkan informasi yang ada pada fitur tugas dan evaluasi pada JBClass, guru bisa melihat langsung tentang waktu pengerjaan dan nilai tugas dan evaluasi tentang materi Narrative text dan Song Lyric dari masing-masing peserta didik yang ada di kelasnya. Jumlah keterlambatan pengum-pulan tugas dan evaluasi dari masing-masing kelas mengalami penurunan.

Tabel dibawah ini menunjukkan perbandingan tentang jumlah peserta didik yang terlambat dalam menyelesaikan tugas dan evaluasi pada materi I Dinamika Atmosfer dan materi II Dampaknya Terhadap Kehidupan. Pada materi Dampaknya Terhadap Kehidupan, keterlambatan pengumpulan tugas dan evaluasinya semakin berkurang.

Tabel 2. Jumlah peserta didik yang terlambat dalam menyelesaikan tugas dan evaluasi

\begin{tabular}{|c|c|c|c|}
\hline No & Kelas & \multicolumn{2}{|c|}{$\begin{array}{r}\text { Jumlah peserta didik yang terlambat dalam } \\
\text { menyelesaikan tugas dan evaluasi }\end{array}$} \\
\hline & & Dinamika Atmosfer & $\begin{array}{c}\text { Dampaknya Terhadap } \\
\text { Kehidupan }\end{array}$ \\
\hline 1 & X IPS 1 & 10 & 3 \\
\hline 2 & X IPS 2 & 8 & 4 \\
\hline
\end{tabular}

Hasil rata-rata nilai tugas dan evaluasi peserta didik untuk materi materi I Dinamika Atmosfer dan materi II Dampaknya Terhadap Kehidupan. Pada materi Dampaknya Terhadap Kehidupan dari masing-masing kelas juga menunjukkan peningkatan, seperti yang ditampilkan pada tabel dibawah ini.

Tabel 3. Rata-rata nilai tugas dan evaluasi

\begin{tabular}{|c|c|c|c|}
\hline No & Kelas & \multicolumn{2}{|c|}{ Rata-rata nilai tugas dan evaluasi } \\
\hline & & Dinamika Atmosfer & $\begin{array}{c}\text { Dampaknya Terhadap } \\
\text { Kehidupan }\end{array}$ \\
\hline 1 & X IPS 1 & 79 & 80 \\
\hline 2 & X IPS 2 & 80 & 83 \\
\hline
\end{tabular}


Dari tabel yang ditampilkan diatas tampak jelas bahwa ada perbedaan nilai rata-rata untuk tugas dan evaluasi dari tiap kelas pada pembelajaran materi Dinamika Atmosfer dan Dampak Terhadap Kehidupan. Pada saat pembelajaran materi Dinamika Atmosfer, jumlah peserta didik tiap kelas yang terlambat pengumpulan tugas dan evaluasinya masih cukup banyak. Begitu juga untuk rata-rata nilai tugas dan evaluasi tiap kelasnya pada materi Dinamika Atmosfer masih ada yang kurang. Sedangkan untuk pembelajaran pada materi Dampaknya Terhadap Kehidupan, jumlah peserta didik yang terlambat pengumpulan tugas dan evaluasinya semakin sedikit. Demikian pula untuk rata-rata nilai tugas dan evaluasi tiap kelasnya pada materi Dampaknya Terhadap Kehidupan juga semakin meningkat dan diatas KKM semua, tetapi jumlah peningkatannya tidak sama.

Dari hasil di atas dapat dikatakan bahwa bahwa manfaat penggunaan media pembelajaran (JBClass) dapat menambah gairah dan motivasi belajar siswa. Pemanfaatan JBClass untuk pembelajaran online selama masa pandemi COVID-19 sangat berdampak pada peserta didik. Mereka merasa lebih nyaman dalam belajar karena bisa menggunakan hp mereka untuk belajar secara online. Pengerjaan tugas / evaluasi juga tidak memerlukan media tambahan seperti laptop, karena tidak semua peserta didik memiliki laptop di rumah. Ketika ada kendala dalam mengikuti pembelajaran online dapat ditanyakan ke guru lewat WA group kelas atau WA pribadi. Hasil pengerjaan tugas/evaluasi peserta didik juga bisa terlihat langsung di layar hp, sehingga mereka mengetahui ketuntasan belajar mereka. Hal ini membuat peserta didik semakin termotivasi untuk bisa mendapatkan nilai tugas dan evaluasi secara tuntas atau lebih baik lagi.

Ketika nilai tugas/evaluasi mereka belum tuntas dan harus remidi, peserta didik juga bisa meminta ijin gurunya untuk di reset kembali waktu pengerjaannya dan melakukan remidi sesuai kesepakatan. Di pihak guru, pemanfaatan JBClass dalam pembelajaran online selama masa pandemi COVID-19 sangat dirasakan manfaatnya. Guru dapat melaksanakan tugas utamanya memberikan layanan pembelajaran.

\section{KESIMPULAN}

Dari pelaksanaan dan hasil yang diperoleh dalam best practice ini dapat disimpulkan bahwa pemanfaatan JBClass yang menggunakan LMS (learning management system) dapat meningkatkan motivasi belajar bahasa Inggris peserta didik kelas X Resmi Bisma Paket C Kalimanah pada masa pandemi COVID-19. Hal tersebut dapat dilihat dari hasil perbandingan pembelajaran pada materi I (Dinamika Atmosfer) dan materi II (Dampaknya Terhadap Kehidupan).

Dengan adanya hasil best practice tersebut diatas, penulis dapat merekomendasikan untuk pemanfaatan JBClass pada pembelajaran pada masa yang akan datang. Aplikasi JBClass sudah mempunyai fitur yang lengkap untuk membuat pembelajaran yang menyenangkan bagi peserta didik (bisa diikuti dengan menggunakan hp), dan juga memudahkan guru untuk mengelola pembelajaran online karena sudah menyediakan fitur materi, latihan, tugas, evaluasi dan rekap nilai untuk tiap-tiap kelas maya yang diampunya.

Bahwa pada pembelajaran materi kedua, jumlah peserta didik yang terlambat pengumpulan tugas dan evaluasinya semakin sedikit dibandingkan dengan pembelajaran materi pertama. Begitu juga untuk rata-rata nilai tugas dan evaluasi tiap kelas pada pembelajaran materi kedua menunjukkan nilai yang lebih tinggi dibandingkan nilai rata-rata kelas pada materi pertama, walaupun peningkatannya tidak sama untuk setiap kelas karena karakteristik peserta didik yang berbeda.

\section{DAFTAR PUSTAKA}

[1] Anderson,Terry. 2008. TheTheory andPractice of Online Learning 2 nd edition.Edmonton: Athabasca University Press.

[2] Atfillah, Dela. (2015). Hubungan antara Iklim Sekolah dengan motivasi belajar siswa SMK Perbankan Padang. Skripsi: Fakultas Psikologi Universitas Putra Indonesia "YPTK" Padang".

[3] Kemdikbud. 2018. Kamus besar Bahasa Indonesia Edisi Kelima. Jakarta: Adi Perkasa.

[4] Djamarah, Syaiful Bahri. (2011). Psikologi Belajar. Jakarta: Rineka Cipta.

[5] Jati, Gumawang. (2013). Learning Management System (moodle) and ELearning Content Development. Jurnal Sosioteknologi edisi 28 tahun 12: April 2013.

[6] Martin, Andrew. (2020). How to Optimize Online Learning in the Age of Coronavirus (COVID-19): A 5-point Guide for Educators. from https://newsroom.unsw.edu.au/news/socia 1-affairs/how-optimise-onlinelearningage- coronavirus.

[7] Sanjaya, Wina. (2013). Strategi Pembelajaran Berorientasi Standar Proses Pendidikan. Jakarta: Kencana Prenadamedia Group. Sardiman. (2014). Interaksi Dan Motivasi Belajar Mengajar. Jakarta: PT Raja Grafindo Persada.

[8] Shoimin, Aris. (2014). 68 Model Pembelajaran Inovatif dalam Kurikulum 2013. Yogyakarta: Ar-Ruzz Media. 